\title{
Morphology and morphometry of the foramen magnum in Toy Poodle and Yorkshire terrier dogs
}

\author{
Morfologia e morfometria do forame magno em cães das raças Poodle Toy e Yorkshire terrier
}

\author{
Carina Outi Baroni' ${ }^{*}$ Ana Carolina Brandão de Campos Fonseca Pinto ${ }^{\mathrm{I}}$ Julia Maria Matera ${ }^{\mathrm{I}}$ \\ Christina Mahrenholz Kaufmann Chamone ${ }^{I}$ Ayne Murata Hayashi ${ }^{I}$
}

\begin{abstract}
The occipital dysplasia has been characterized by a dorsal enlargement of the foramen magnum which can vary in size and shape. Clinical signs may be present or not in animals with occipital dysplasia. The purpose of this study was to radiographically analyze the morphology and morphometry of the foramen magnum of thirty healthy dogs. This study chose to use fifteen Yorkshire terrier dogs and fifteen Toy Poodle dogs in order to characterize the radiographic aspects of the foramen magnum and contribute to the diagnosis and critical analysis of the occipital dysplasia importance. According to the foramen magnum morphology and tracings, it was possible to classify the radiographic aspects into different shapes varing from oval and quadrangular. Out of 26 (86.7\%) animals had a dorsal enlargement and $4(13.3 \%)$ showed normal foramen magnum. Animals without any clinical signs that are radiographically classified as dysplastic dogs may simply represent an anatomic variation of the foramen magnum.
\end{abstract}

Key words: foramen magnum, occipital bone, dysplasia, Poodle Toy, Yorkshire terrier.

\section{RESUMO}

A displasia do occipital é o alargamento dorsal do forame magno, o qual pode variar a sua forma e tamanho e os animais com esta alteração morfológica podem ou não apresentar manifestações clínicas. $O$ objetivo desta pesquisa foi avaliar radiograficamente a morfologia e a morfometria do forame magno de 30 cães assintomáticos das raças Poodle toy e Yorkshire terrier, sendo 15 de cada, a fim de se caracterizar os aspectos radiográficos do forame magno e contribuir para o diagnóstico e análise crítica da relevância da displasia do occipital. O forame magno apresentou aspectos que variaram de oval a quadrangular. A presença do alargamento dorsal ocorreu em 26 (86,7\%) animais e a ausência em apenas quatro $(13,3 \%)$. Animais sem manifestações clínicas, que apresentam graus variados de alargamento dorsal e são classificados radiograficamente como displásicos, podem apenas representar variações anatômicas do forame magno.

Palavras-chave: forame magno, osso occipital, displasia, Poodle toy e Yorkshire terrier.

\section{INTRODUCTION}

Occipital dysplasia has been characterized by a dorsal midline notch of the foramen magnum into the occipital bone, which can vary in shape and size (PARKER \& PARK, 1974a; DE LAHUNTA, 1983; ETTINGER, 1995; BAGLEY et al., 1996). It is the result of the incomplete ossification of the ventromedial part of the supraoccipital bone, (PARKER \& PARK, 1974a; DE LAHUNTA, 1983; WATSON et al., 1989). Some animals present a membranous tissue on the dorsal enlargement covering the caudal portion of the cerebellum (DE LAHUNTA, 1983; WATSON et al., 1989; SIMOENS et al., 1994; CERDA-GONZALEZ, 2009) which may prevent the prolapse of cerebellum or brain stem through the enlarged opening (SIMOENS et al., 1994; RUSBRIDGE \& KNOWLER, 2006; CERDAGONZALEZ, 2009). The foramen magnum can have many shapes: oval (EVANS, 1993; SIMOENS et al., 1994), rectangular (SIMOENS et al., 1994) and, in the

'Departamento de Cirurgia, Faculdade de Medicina Veterinária e Zootecnia (FMVZ), Universidade de São Paulo (USP). Av. Prof. Orlando Marques de Paiva, 87, Cidade Universitária Armando de Salles Oliveira, 05508-270,São Paulo, SP, Brasil. Email: carinaouti@yahoo.com.br.* Autor para correspondência. 
brachycephalic skulls, can be circular and asymmetric (WATSON et al., 1989; EVANS, 1993).

Occipital dysplasia has been associated to small breeds (KELLY, 1975; ETTINGER, 1995). The most commonly affected breeds are: Beagle, Lhasa apso, Maltese, Shih tzu (PARKER \& PARK, 1974b), Cavalier King Charles Spaniel (RUSBRIDGE \& KNOWLER, 2006; COUTURIER et al., 2008; CERDA-GONZALEZ, 2009), Chihuahua (PARKER \& PARK, 1974b; WATSON et al., 1989), Pomeranian (WATSON et al., 1989), Pekingese (SIMOENS et al., 1994), Toy Poodle (KELLY, 1975) and Yorkshire terrier (PARKER \& PARK, 1974b; BAGLEY et al., 1996).

The clinical importance of occipital dysplasia is questionable, because the animals may be asymptomatic and it is rarely associated with neurologic problems (PARKER \& PARK, 1974b; KELLY, 1975). Some authors list as possible clinical signs: ataxia (PARKER \& PARK, 1974b; KELLY, 1975), cervical pain (PARKER \& PARK, 1974b; KELLY, 1975), convulsions (PARKER \& PARK, 1974b; KELLY, 1975), behavior changes (KELLY, 1975), dysphagia (PARKER \& PARK, 1974b), depression, blindness and strabismus (PARKER \& PARK, 1974b).

When the animal presents some of these clinical signs, especially when convulsions and ataxia were observed (KELLY, 1975), the differential diagnosis with hydrocephalus (PARKER \& PARK, 1974b; KELLY, 1975;), Chiari-like malformation (DEWEY et al., 2005; RUSBRIDGE \& KNOWLER, 2006; DEWEY et al., 2007; COUTURIER et al., 2008; CERDA-GONZALEZ, 2009), syringomyelia (RUSBRIDGE \& KNOWLER, 2006) and other disorders that compromise the spinal cord (BAGLEY et al., 1996) must be considered. Further researches, including computed tomography and magnetic resonance imaging should be made to better investigate the relationship between these diseases (RUSBRIDGE \& KNOWLER, 2006).

One study about the morphometry of the foramen magnum proposes to graduate the severity of the occipital dysplasia by the proportion of the length of the dorsal notch $(\mathrm{N})$ and the height of the foramen magnum (h). Grade 1 is a dorsal notch of the foramen magnum of less than one half of its expected height (N/ $\mathrm{h}<0,5$ ); grade 2 is a dorsal notch that approximately doubles the expected height of foramen magnum $(\mathrm{N} / \mathrm{h} \sim$ 1) and grade 3 is any dorsal notch in excess of grade 2 $(\mathrm{N} / \mathrm{h}>1$ ) (PARKER \& PARK, 1974b).

Another research observed the range of normal variation in size and shape of the foramen magnum of Pekingese dogs and the results showed that the variability in the area was mainly correlated with total height of the foramen magnum (SIMOENS et al., 1994).
The purpose of this study was to radiographically evaluate the foramen magnum and classify its aspects in two dog breeds that are frequently related to the occipital dysplasia.

\section{MATERIALS AND METHODS}

In this study, 30 asymptomatic dogs, 15 Toy Poodles and 15 Yorkshire terriers, were selected, following individual analysis protocols that included identification, clinical history, physical and neurological examination.

Out of 15 Toy Poodle, 6 dogs were male and nine were female, with an age group between 9 months and 11 years and weight body from $2,30 \mathrm{~kg}$ to $8,30 \mathrm{~kg}$. Seven out of 15 Yorkshire terrier dogs were male and eight were female, with an age group between 11 months and 8 years and weight body from $2,55 \mathrm{~kg}$ to $8,80 \mathrm{~kg}$.

Of these animals, 9 were positioned without any chemical restraint and the other 21 were tranquilized with acepromazine $\left(0,1 \mathrm{mg} \mathrm{kg}^{-1}\right.$, i.m. $)$ and meperidine $\left(4,0 \mathrm{mg} \mathrm{kg}^{-1}\right.$,i.m.).

Ventrodorsal projection was made with vertical X-ray beam to visualize the odontoid process and lateral projection for the evaluation of the cervical area to exclude other abnormalities. Rostrocaudal projection was chosen to observe the foramen magnum, with the animal in dorsal decumbency, a vertical X-ray beam and with the zigomatic arch with an angle from $45^{\circ}$ to $75^{\circ}$ to the table.

To analyze the morphometry some variables were checked: height (h), height of dorsal notch $(\mathrm{N})$, total height $(\mathrm{H}=\mathrm{N}+\mathrm{h})$, width $(\mathrm{W})$ and area (A) (PARKER \& PARK 1974b, WATSON et al., 1989; SIMOENS et al., 1994) (Figure 1). All the measurements were established with the help of a precision pachymeter of $0,02 \mathrm{~mm}$ and to calculate the area one specific software was used. For that, the radiographic images were imported into AutoCAD program (AutoCAD, 2006), the perimeters of foramen magnum were plotted manually and the software automatically calculates the area.

\section{RESULTS AND DISCUSSION}

The radiographic evaluation of the cervical spine cord and the dens axis of all studied animals was enough to exclude any possible radiographic bone alterations of this region that could coexist with the dorsal notch of the foramen magnum.

The average and standard deviation of total height of the foramen magnum were $18.5 \mathrm{~mm} \pm 4.1 \mathrm{~mm}$, dorsal notch $4.6 \mathrm{~mm} \pm 4.6 \mathrm{~mm}$, expected high 

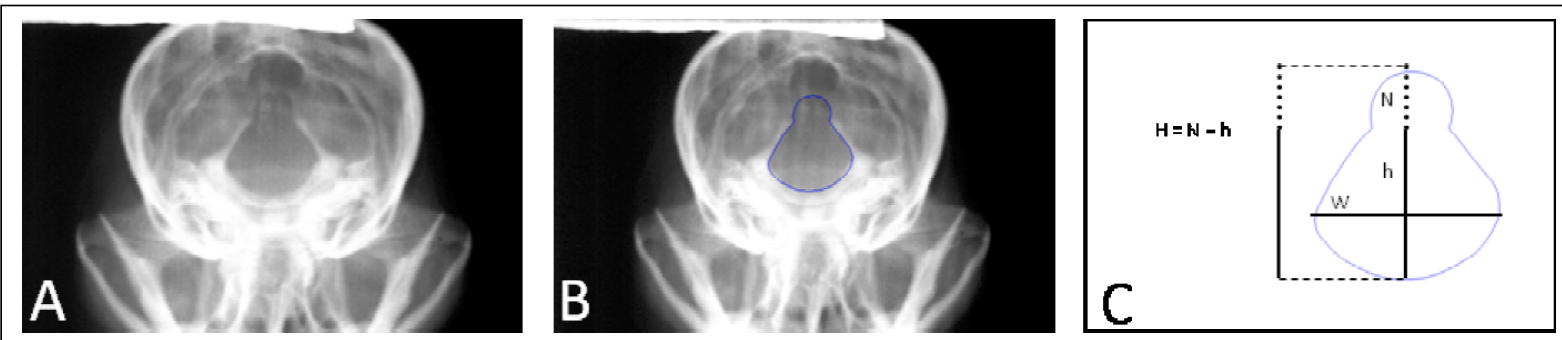

Figure 1 - A: Digitized image of skull radiography from a Toy Poodle with dorsal enlargement of the foramen magnum. B: Digitized image of skull radiography from the same animal with a blue outline standing the foramen magnum out. C: Contour drawing of the foramen magnum from the same animal illustrating the analysis scheme of the foramen magnum morphometry. $\mathrm{H}=$ total height, $\mathrm{N}=$ height of dorsal notch, $\mathrm{W}=$ width of the foramen magnum, $\mathrm{h}=$ expected height of the foramen magnum, $\mathrm{w}=$ width of the dorsal notch .

$13.9 \mathrm{~mm} \pm 1.5 \mathrm{~mm}$, width $17.7 \mathrm{~mm} \pm 0.9 \mathrm{~mm}$ and area $213.8 \mathrm{~mm}^{2} \pm 34.6 \mathrm{~mm}^{2}$ from Toy Poodle. The average and standard deviation of total height of the foramen magnum were $19.8 \mathrm{~mm} \pm 3.1 \mathrm{~mm}$, dorsal notch $6.7 \mathrm{~mm} \pm 3.5 \mathrm{~mm}$, expected high $13.0 \mathrm{~mm} \pm 0.8 \mathrm{~mm}$, width $16.5 \mathrm{~mm} \pm 0.8 \mathrm{~mm}$ and area $222.0 \mathrm{~mm}^{2} \pm 40.5 \mathrm{~mm}^{2}$ from Yorkshire terrier (Tables 1,2). Total height of foramen magnum was divided by width and this measurement demonstrated the contribution of the total height in the variability of its aspects. In similar way SIMOENS

Table 1 - Measurements of the Foramen Magnum: total height, height of dorsal notch and its expected height from the 30 Toy Poodle Dogs listed from 1 to 15.

\begin{tabular}{lrlrrl}
\hline Number & $\mathrm{H} *$ & $\mathrm{~N} \dagger$ & $\mathrm{h} \dagger$ & $\mathrm{W} \|$ & $\mathbf{A}$ \\
\hline $\mathbf{1}$ & 17,5 & $\mathbf{0}$ & $\mathbf{1 7 , 5}$ & $\mathbf{1 9 , 7}$ & 230,3 \\
$\mathbf{2}$ & 16,0 & $\mathbf{0}$ & 16,0 & 19,0 & 216,8 \\
$\mathbf{3}$ & 15,1 & $\mathbf{0}$ & 15,1 & 18,7 & 226,0 \\
$\mathbf{4}$ & $\mathbf{1 3 , 8}$ & $\mathbf{0}$ & 13,8 & 17,3 & 179,4 \\
$\mathbf{5}$ & 16,5 & 3,5 & 13,0 & $\mathbf{1 6 , 3}$ & 171,2 \\
$\mathbf{6}$ & 16,9 & 3,7 & 13,2 & 17,2 & $\mathbf{1 6 7 , 2}$ \\
$\mathbf{7}$ & 16,8 & 3,9 & 12,9 & 17,8 & 211,7 \\
$\mathbf{8}$ & 18,0 & 4,0 & 14,0 & 18,4 & 212,5 \\
$\mathbf{9}$ & 18,1 & 4,2 & 13,9 & 18,0 & 215,0 \\
$\mathbf{1 0}$ & 18,8 & 5,0 & 13,8 & 17,6 & 216,2 \\
$\mathbf{1 1}$ & 16,9 & 5,9 & $\mathbf{1 0 , 9}$ & 16,9 & 188,2 \\
$\mathbf{1 2}$ & 20,9 & 6,3 & 14,6 & 17,3 & 217,9 \\
$\mathbf{1 3}$ & 19,8 & 6,8 & 13,0 & 17,4 & 233,6 \\
$\mathbf{1 4}$ & 19,9 & 6,9 & 13,0 & 17,1 & 201,9 \\
$\mathbf{1 5}$ & $\mathbf{3 2 , 1}$ & $\mathbf{1 9 , 1}$ & 13,0 & 17,0 & $\mathbf{3 1 9 , 5}$ \\
Average & $\mathbf{1 8 , 5}$ & $\mathbf{4 , 6}$ & $\mathbf{1 3 , 9}$ & $\mathbf{1 7 , 7}$ & $\mathbf{2 1 3 , 8}$ \\
Standard & $\mathbf{4 , 1}$ & $\mathbf{4 , 6}$ & $\mathbf{1 , 5}$ & $\mathbf{0 , 9}$ & $\mathbf{3 4 , 6}$ \\
deviation & & & & & \\
\hline
\end{tabular}

Footnotes: Unit in millimeters $[\mathrm{mm}]$ and area in $\left[\mathrm{mm}^{2}\right] . * \mathrm{H}=$ total height $(\mathrm{N}+\mathrm{h})$.

$\dagger \mathrm{N}=$ height of dorsal notch. $\ddagger \mathrm{h}=$ expected height of the foramen magnum. $\| \mathrm{W}=$ width of the foramen magnum. If $\mathrm{A}=$ area. et al. (1994) observed that the total height was the most relevant factor to the variability in the area. The subjective analyses of the foramen magnum can difficulty the radiographic interpretation so, measures are important in order to establish the size of the foramen magnum and the final radiographic diagnosis in different affected breeds.

According to the occipital dysplasia grading classification (PARKER \& PARK, 1974b), 4

Table 2 - Measurements of the Foramen Magnum: total height, height of dorsal notch and its expected height from the 30 Yorkshire Terrier Dogs listed from 16 to 30 .

\begin{tabular}{lrrrrc}
\hline Number & $\mathrm{H} *$ & $\mathrm{~N} \dagger$ & $\mathrm{h} \ddagger$ & $\mathrm{W} \|$ & $\mathrm{A}$ \\
\hline $\mathbf{1 6}$ & $\mathbf{1 4 , 5}$ & $\mathbf{1 , 4}$ & 13,1 & $\mathbf{1 7 , 9}$ & 179,3 \\
$\mathbf{1 7}$ & 16,8 & 3,6 & 13,2 & 17,3 & 183,9 \\
$\mathbf{1 8}$ & 17,3 & 4,3 & 13,0 & 15,8 & $\mathbf{1 7 5 , 5}$ \\
$\mathbf{1 9}$ & 18,6 & 4,6 & 14,0 & 16,8 & 186,9 \\
$\mathbf{2 0}$ & 18,8 & 4,8 & 14,0 & 17,5 & 213,5 \\
$\mathbf{2 1}$ & 17,8 & 5,0 & 12,8 & 16,0 & 212,4 \\
$\mathbf{2 2}$ & 18,3 & 5,1 & 13,2 & 16,8 & 193,7 \\
$\mathbf{2 3}$ & 20,0 & 5,3 & $\mathbf{1 4 , 7}$ & 16,4 & 215,7 \\
$\mathbf{2 4}$ & 18,2 & 5,4 & 12,8 & 16,7 & 222,9 \\
$\mathbf{2 5}$ & 18,8 & 5,9 & 12,9 & 15,7 & 197,7 \\
$\mathbf{2 6}$ & 21,8 & 8,4 & 12,8 & 17,3 & 230,0 \\
$\mathbf{2 7}$ & 21,0 & 9,3 & 11,7 & 16,0 & 236,1 \\
$\mathbf{2 8}$ & 22,7 & 11,2 & $\mathbf{1 1 , 5}$ & $\mathbf{1 5 , 5}$ & 279,6 \\
$\mathbf{2 9}$ & 25,0 & 13,0 & 12,0 & $\mathbf{1 5 , 5}$ & 295,4 \\
$\mathbf{3 0}$ & $\mathbf{2 6 , 9}$ & $\mathbf{1 3 , 9}$ & 13,0 & 15,7 & $\mathbf{3 0 8 , 1}$ \\
Average & 19,8 & 6,7 & 13,0 & 16,5 & 222,0 \\
Standard & 3,1 & 3,5 & 0,8 & 0,8 & 40,5 \\
deviation & & & & & \\
\hline
\end{tabular}

Footnotes: Unit in millimeters $[\mathrm{mm}]$ and area in $\left[\mathrm{mm}^{2}\right] . * \mathrm{H}=$ total height $(\mathrm{N}+\mathrm{h})$.

$\dagger \mathrm{N}=$ height of dorsal notch. $\ddagger \mathrm{h}=$ expected height of the foramen magnum. $\| \mathrm{W}=$ width of the foramen magnum. If $\mathrm{A}=$ area. 
$(26,7 \%)$ out of the 15 Toy Poodle dogs did not have a dorsal notch of the foramen magnum, $10(66,7 \%)$ showed grade 1 and one $(6,7 \%)$ showed grade 3 . Among the Yorkshire terriers, $10(66,7 \%)$ presented grade $1,3(20 \%)$ grade 2 and $2(13,3 \%)$ presented grade 3 (Figure 2). Although, the animals of this study were free from neurologic sings, the grading classification doesn't seem to have connection with clinical signs.

The radiographic exam is enough to diagnose occipital dysplasia. Nevertheless, radiographic examination detects only the incomplete ossification of the occipital bone and doesn't have sensitivity to detect the presence or absence of membranous tissue or cerebellar herniation so, in symptomatic animals the use of MRI and CT could contribute more for the establishment of the definitive diagnosis (RUSBRIDGE \& KNOWLER, 2006).

The radiographic shapes of the animal of this study were classified into two groups: 9 (30\%) quadrangular and 21 (70\%) oval, among Poodle toys had $4(26,7 \%)$ animals with quadrangular aspects and $11(73,3 \%)$ oval; Yorkshire terriers had $5(33,3 \%)$ animals with quadrangular aspects and $10(66,7 \%)$ oval (Figure 3) and in line with WATSON et al. (1989) and SIMOENS et al. (1994) that considered that the foramen magnum morphology could be variable.

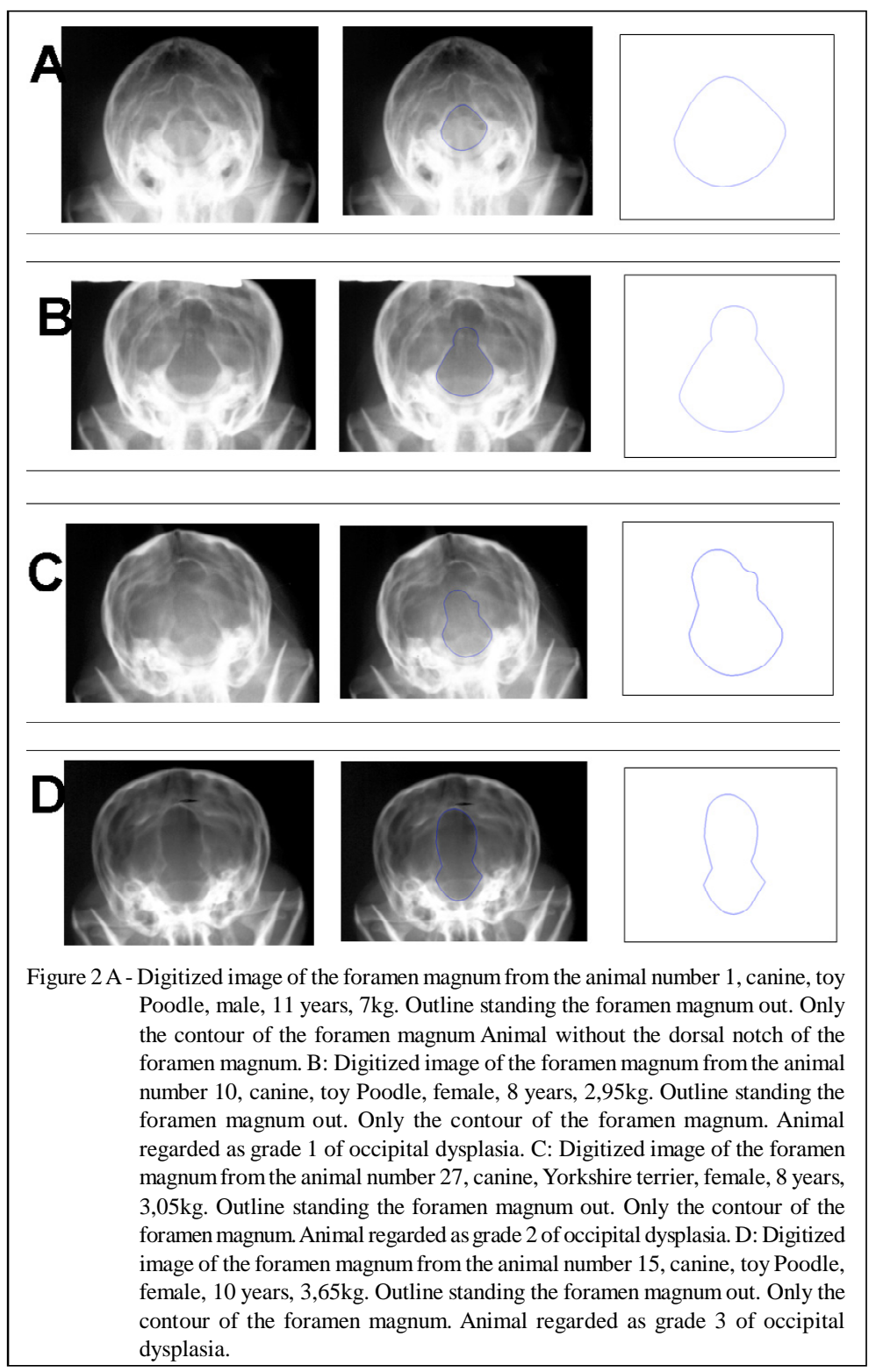

Ciência Rural, v.41, n.7, jul, 2011. 


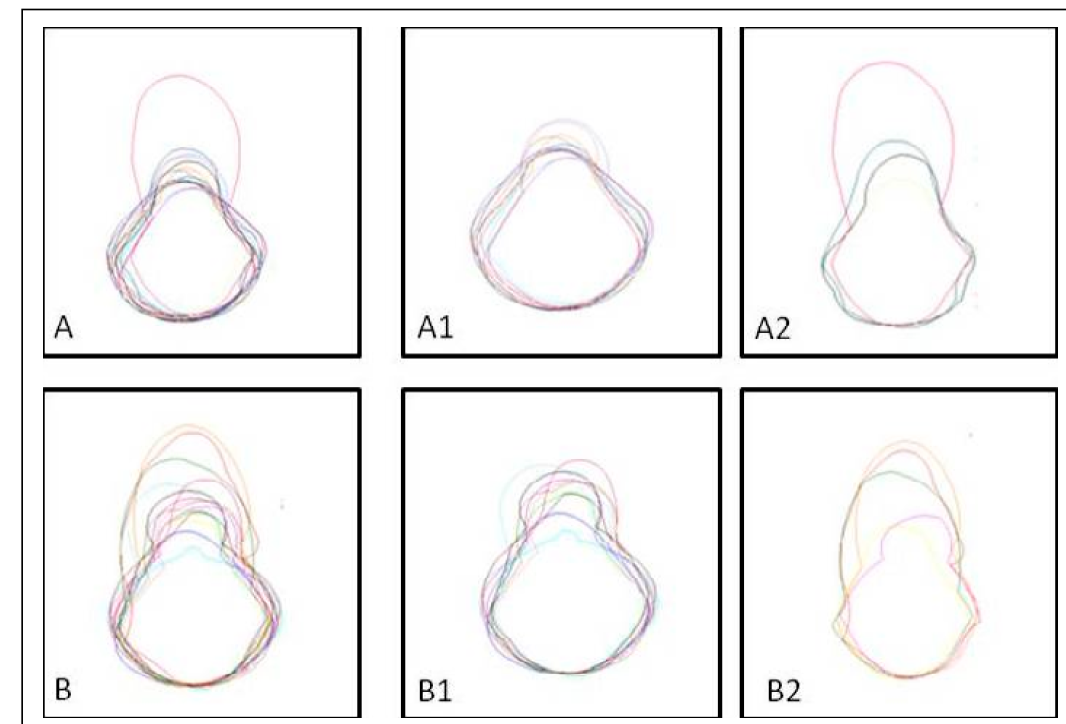

Figure 3 A - Morphologic variation of the foramina magna of the 15 Toy Poodle dogs. Overlapping of the contour lines of all foramina magna. A1: Oval aspect $\mathrm{f}$ the foramina magna of 11 Toy Poodle dogs. A2 Quadrangular aspect of the foramina magna of 4 Toy Poodle dogs. B Morphologic variation of the foramina magna of the 15 Yorkshire terrier dogs. Overlapping of the contour lines of all foramina magna. B1 Oval aspect $\mathrm{f}$ the foramina magna of 10 Yorkshire terrier dogs. B2 Quadrangular aspect of the foramina magna of 5 Yorkshire terrier dogs.

\section{CONCLUSION}

The connection between the radiographic diagnosis and the conclusive clinical diagnosis to establish prognosis and possible treatment of the occipital dysplasia is still unknown, since many animals that are radiographically dysplastic don't present any neurologic signs. So, asymptomatic animals that present varied dorsal enlargements grades and are radiographically classified as dysplastic may simply represent an anatomic variation.

Therefore, animals with neurological signs consistent with abnormalities of the cervicomedullary and presence of occipital dysplasia, should be evaluated by MRI or CT in order to establish the definitive diagnostic.

\section{ACKNOWLEDGMENTS}

The authors thank Fundação de Amparo à Pesquisa do Estado de São Paulo - FAPESP (The State of São Paulo Research) for financial support.

The authors thank Mechanical Engineer Herwin Saito Schultz for statistical analyses and with the computer program used for radiographic images analysis and Veterinarian Lenin A.V. Martinez for technical assistance.

\section{BIOETHIC COMMISSION}

The research was approved by Bioethic Commission of School of Veterinary Medicine and Zootechny of University of São Paulo. Protocol number 1018/2006.

\section{REFERENCES}

AutoCAD. Software CAD, 2006. Autodesk, Inc. Available from: <http://www.autodesk.com.br/adsk/servlet/pc/ index?siteID=1003425\&id=14677991>. Accessed: Mar 19, 2011.

BAGLEY, R.S. et al. Occipital dysplasia and associated cranial spinal cord abnormalities in two dogs. Veterinary Radiology \& Ultrasound, v.37, n.5, p.359-362, 1996. Available from: $<$ http://onlinelibrary.wiley.com/doi/10.1111/j.17408261.1996.tb01243.x/abstract>. Accessed: Mar 19, 2011. doi: 10.1111/j.1740-8261.1996.tb01243.x.

CERDA-GONZALEZ, S. et al. Morphology of the caudal fossa in Cavalier King Charles Spaniels. Veterinary Radiology \& Ultrasound, v.50, n.1, p.37-46, 2009. Available from: বhttp:/ /onlinelibrary.wiley.com/doi/10.1111/j.17408261.2008.01487. $\mathrm{x} /$ abstract? systemMessage $=$ There + will $+\mathrm{b}$ $\mathrm{e}+\mathrm{a}+\mathrm{rel}$ e a s e + of $+\mathrm{W}$ i l e y + Onlin e $+\mathrm{Library}$ $+\mathrm{scheduled}+$ for $+\mathrm{S}$ und a $+19 \mathrm{th}+\mathrm{Dec}$ e mber + $2010 .+$ Access + to + the + website+will+be+disrupted+as + follows\%3 A+New+York+0500+EDT +to+0700+E $\mathrm{D}$ T $\% 3 \mathrm{~B}+\mathrm{L}$ on do n $+1000+\mathrm{G} \mathrm{M} \mathrm{T}+\mathrm{to}+1200$ +GMT\%3B+Singapore+1800+SGT+to+2000+SGT>. Accessed: Mar 19, 2011. doi: 10.1111/j.1740-8261.2008.01487.x. 
COUTURIER, J. et al. Chiari-like malformation and syringomyelia in normal cavalier King Charles spaniels: a multiple diagnostic imaging approach. Journal of Small Animal Practice, v.49, p.438-443, 2008. Available from: <http://onlinelibrary.wiley.com/doi/10.1111/j.17485827.2008.00578.x/abstract>. Accessed: Mar 19, 2011. doi: $10.1111 /$ j.1748-5827.2008.00578.x.

DE LAHUNTA, A. The development of the nervous sistem. In: _____- Veterinary neuroanatomy and clinical neurology. 2.ed. Philadelphia: Saunders, 1983. p. 28.

DEWEY, C.W. et al. Foramen magnum decompression for treatment of caudal occipital malformation syndrome in dogs. Journal of American Veterinary Medical Association, v.227, n.8, p.1270-1275, 2005. Available from: <http:// onlinelibrary.wiley.com/doi/ $10.1111 /$ j. 1532 950X.2007.00286.x/full>. Accessed: Mar 19, 2011. doi: $10.1111 / \mathrm{j} .1532-950 X .2007 .00286 . x$.

DEWEY, C.W. et al. Foramen magnum decompression with cranioplasty for treatment of caudal occipital malformation syndrome in dogs. Veterinary Surgery, v.36, p.406-415, 2007. Available from: <http://onlinelibrary.wiley.com/doi/ 10.1111/j.1532-950X.2007.00286.x/full>. Accessed: Mar 19, 2011. doi: 10.1111/j.1532-950X.2007.00286.x.

ETTINGER S.J.; FELDMAN E.C. Congenital defects of the dog. In: JONNY, D.H. Textbook of veterinary internal medicine. 4.ed. Philadelphia: Saunders, 1995. V.2, p.2115.
KELLY, J.H. Occipital dysplasia and hydrocephalus in a toy poodle. Veterinary medicine small animal clinician, v.70, p.940-941, 1975.

PARKER, A.J.; PARKER R.D. Unusual deformity of the occipital bone in a dog (a case report). Veterinary Medicine Small Animal Clinician, v.69, p.438-441, 1974a.

PARKER, A.J.; PARKER R.D. Occipital dysplasia in the dog. Journal of the American Animal Hospital Association, v. 10 , p.520-525, 1974 b.

RUSBRIDGE, C.; KNOWLER S.P. Coexistence of occipital dysplasia and occipital hypoplasia/ syringomyelia in the cavalier King Charles spaniel. Journal of Small Animal Practice, v.47, n.10, p.603-606, 2006. Available from: <http:// onlinelibrary.wiley.com/doi/10.1111/j. 1748 5827.2006.00048.x/abstract>. Accessed: Mar 19, 2011. doi: $10.1111 /$ j.1748-5827.2006.00048.x.

SIMOENS, P. et al. Morphometric analysis of the foramen magnum in a Pekingese dogs. American Journal of Veterinary Research, v.55, n.1, p.34-39, 1994.

WATSON, A.J. et al. Dorsal notch of the foramen magnum due to incomplete ossification of the supraoccipital bone in dogs. Journal of Small Animal Practice, v.30, p.666-673, 1989. 